\title{
Silver Concentrations and Selected Hydrologic Data in the Upper Colorado River Basin, 1991-92
}

by David A. Johncox

\section{U.S. GEOLOGICAL SURVEY}

Open-File Report 93-447

Prepared in cooperation with the COLORADO RIVER WATER CONSERVATION DISTRICT and the NORTHERN COLORADO WATER CONSERVANCY DISTRICT

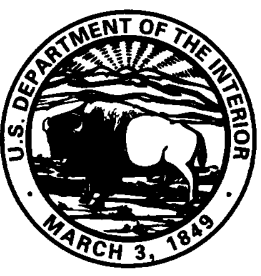




\section{U.S. DEPARTMENT OF THE INTERIOR BRUCE BABBITT, Secretary}

U.S. GEOLOGICAL SURVEY

Robert M. Hirsch, Acting Director

The use of trade, product, industry, or firm names is for descriptive purposes only and does not imply endorsement by the U.S. Government.

For additional information write to:

Copies of this report can be purchased from:

District Chief

U.S. Geological Survey

Box 25046, MS 415

Denver Federal Center

Denver, CO 80225
U.S. Geological Survey

Earth Science Information Center

Open-File Reports Section

Box 25286, MS 517

Denver Federal Center

Denver, CO 80225 


\section{CONTENTS}

Abstract

Introduction

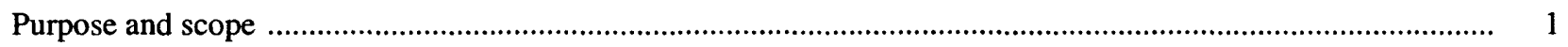

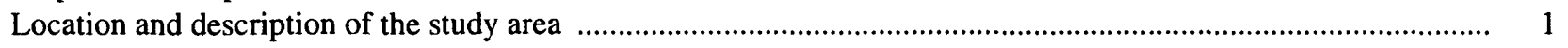

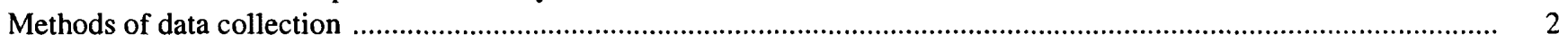

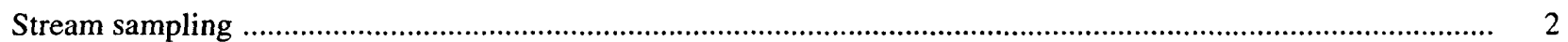

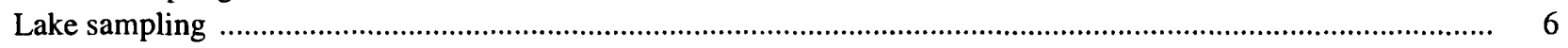

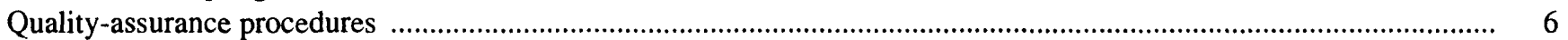

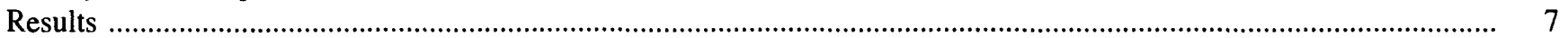

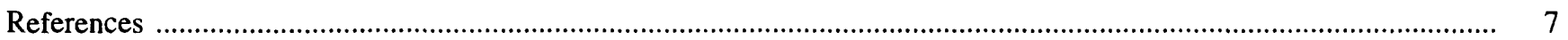

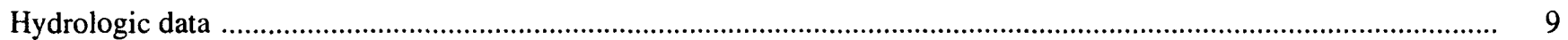

\section{FIGURES}

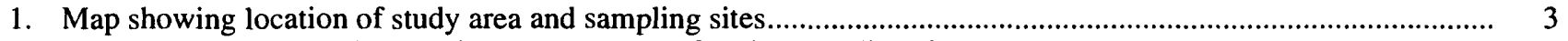

2. Map showing Shadow Mountain Lake and Lake Granby sampling sites....................................................

\section{TABLES}

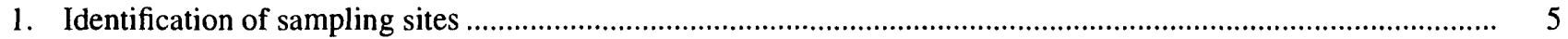

2. Silver concentrations and selected hydrologic data for stream-sampling sites........................................................ $\quad 10$

3. Silver concentrations and selected hydrologic data for Shadow Mountain Lake and Lake Granby ........................ $\quad 12$

\section{CONVERSION FACTORS AND ABBREVIATIONS}

\begin{tabular}{rrl}
\hline Multiply & \multicolumn{1}{c}{ By } & To obtain \\
\hline acre-foot (acre-ft) & & \\
foot $(\mathrm{ft})$ & $1,233.49$ & cubic meter \\
inch (in.) & 0.3048 & meter \\
mile $(\mathrm{mi})$ & 25.4 & millimeter \\
liter $(\mathrm{L})$ & 1.609 & kilometer \\
gallon (US) & inch \\
micrometer $(\mu \mathrm{m})$ & 0.2642 & fluid ounce \\
\hline
\end{tabular}

The following terms and abbreviations also are used in this report:

microgram per gram $(\mu \mathrm{g} / \mathrm{g})$

microgram per liter $(\mu \mathrm{g} / \mathrm{L})$

Degree Celsius $\left({ }^{\circ} \mathrm{C}\right)$ may be converted to degree Fahrenheit $\left({ }^{\circ} \mathrm{F}\right)$ by using the following equation:

$$
{ }^{\circ} \mathrm{F}=9 / 5\left({ }^{\circ} \mathrm{C}\right)+32 .
$$




\title{
Silver Concentrations and Selected Hydrologic Data in the Upper Colorado River Basin, 1991-92
}

\author{
ByDavid A. Johncox
}

\section{Abstract}

The U.S. Geological Survey, in cooperation with the Colorado River Water Conservation District and the Northern Colorado Water Conservancy District, collected water and sediment samples in May and September 1991 and 1992 from nine stream-sampling sites and three lakesampling sites within the Upper Colorado River Basin upstream from Kremmling, Colorado. Data were collected to determine the present (1992) conditions of the Upper Colorado River Basin regarding silver concentrations in the water and sediment. Lake-water and stream-water samples were analyzed for concentrations of total recoverable silver, dissolved silver, and suspended solids. Lake and stream-bottom material was analyzed for concentrations of total recoverable silver. Additional data collected were streamflow, specific conductance, $\mathrm{pH}$, and water temperature. Transparency (Secchi-disk measurements) also was measured in the lakes.

Results of the 156 samples analyzed indicated no detectable silver concentrations in the water or sediment.

\section{INTRODUCTION}

During the spring of 1989 , higher than normal dissolved-silver concentrations were reported at several U.S. Geological Survey (USGS) water-quality sampling sites within the Upper Colorado River Basin upstream from Kremmling, Colo. These water-quality anomalies caused concern by the Colorado River Water Conservation District (CRWCD) and the Northern Colorado Water Conservancy District (NCWCD). The Class 1 cold-water aquatic life silver standard of $0.1 \mu \mathrm{g} / \mathrm{L}$ (U.S. Environmental Protection Agency, 1986) had been exceeded substantially, which prompted the CRWCD and NCWCD to request a reconnaissance study. In May 1991, the U.S. Geological Survey, in cooperation with the CRWCD and NCWCD began a reconnaissance of the Upper Colorado River Basin upstream from Kremmling, Colo., to determine silver concentrations in the water and sediment.

\section{Purpose and Scope}

This report presents silver concentrations and selected hydrologic data collected at stream and lake sites in the Upper Colorado River Basin upstream from Kremmling, Colo., and it describes sampling-site locations and methods of data collection of the water and sediment. Total recoverable silver, dissolved silver, total silver in the bottom material, and suspended solids were the constituents sampled at most of the streamsampling sites and all the lake-sampling sites. Bottom material was not collected at the Willow Creek Pump Canal near Granby and Alva B. Adams Tunnel at East Portal near Estes Park stream-sampling sites due to the concrete channel construction and the resulting absence of bottom material. Specific conductance, $\mathrm{pH}$, water temperature, and transparency were the properties measured at the lake-sampling sites. The two lakes sampled, Shadow Mountain Lake and Lake Granby, are reservoirs; however, they are named as lakes and are referred to as lakes throughout this report.

Sampling began May 1991 and continued in September 1991, May 1992, and September 1992. This sampling schedule allowed a good characterization of the water-quality properties and constituents during periods of high flow and base flow for the streamsampling sites and during periods of high inflow and seasonal drawdown for the lake-sampling sites.

\section{Location and Description of the Study Area}

The study area consisted of nine stream-sampling sites and three lake-sampling sites, most of which are located in the Upper Colorado River Basin in Grand County in north-central Colorado (fig. 1). Sampling site S2 (Alva B. Adams Tunnel at East Portal near Estes Park) receives diverted Colorado River water and is located in Larimer County. Most of the stream-sampling sites were located at or near existing USGS or NCWCD streamflow-gaging stations. The two Lake 
Granby and one Shadow Mountain Lake sampling sites are near established USGS water-quality sampling sites (Ugland and others, 1992, 1993).

Lake Granby is located in eastern Grand County about $7.5 \mathrm{mi}$ northeast of the town of Granby. It is a reservoir formed by dams on the Colorado River (fig. 2) and is part of the Colorado-Big Thompson (C-BT) Project, the largest transmountain diversion project in the State, which is operated by the NCWCD (Brian Werner, NCWCD, written commun., 1993). Water stored in Lake Granby is pumped into Shadow Mountain Lake, which flows into Grand Lake and is diverted through the Alva B. Adams Tunnel to provide supplemental water to municipalities and ditch and reservoir companies for power and irrigation in the South Platte River basin. Lake Granby receives inflow from several natural tributaries, including Arapaho Creek and Stillwater Creek. Diverted water is pumped into Lake Granby, usually during periods of snowmelt runoff, from Windy Gap and Willow Creek Reservoirs. Lake Granby has a total storage capacity of about 540,000 acre-ft.

Shadow Mountain Lake is in eastern Grand County about $3.2 \mathrm{mi}$. south of the town of Grand Lake (fig. 2). It is a reservoir formed by a dam on the Colorado River and is a part of the C-BT Project that is operated by the NCWCD. Water stored in Shadow Mountain Lake flows into Grand Lake and is diverted to the eastern slope of Colorado through the Alva B. Adams Tunnel. C-BT diversion water is pumped in from Lake Granby via the Granby Pump Canal (fig. 2). The combined storage of Shadow Mountain Lake and Grand Lake is about 18,000 acre-ft (Brian Werner, NCWCD, written commun., 1993).

The nine stream sites sampled during this study are shown in figure 1 and are listed in table 1 from the most upstream site to the farthest downstream. The Willow Creek Pump Canal near Granby and Fraser River below Granby sites are gaging stations operated by the NCWCD. The remainder of the stream sites are USGS gaging stations with the exception of Arapaho Creek below Monarch Lake, which is an abandoned USGS site.

\section{METHODS OF DATA COLLECTION}

Water and bottom-material samples were collected at stream- and lake-sampling sites in May and September 1991 and 1992. Samples were collected using standard techniques (Guy and Norman, 1970; Edwards and Glysson, 1988; Ward and Harr, 1990). These methods are described in the following sections. The sites sampled during this study are listed in table 1 and are shown in figures 1 and 2.
Water samples were analyzed for concentrations of suspended solids and total recoverable and dissolved silver. Chemical analyses of water samples were done at the USGS National Water Quality Laboratory in Arvada, Colo. Analyses were done according to the standard methods described by Fishman and Friedman (1989). A custom graphite furnace technique was used for low-level dissolved silver analysis to obtain a detection limit of $0.2 \mu \mathrm{g} / \mathrm{L}$. Total recoverable silver analysis was done with an atomic absorption graphite furnace method for a detection limit of $1.0 \mu \mathrm{g} / \mathrm{L}$.

Bottom-material samples were analyzed for total recoverable silver by the U.S. Geological Survey Branch of Geochemistry Laboratory in Lakewood, Colo. These bottom materials were analyzed using inductively coupled plasma-atomic emission spectrometry (ICP-AES) techniques as described in Baedecker (1987) with a detection limit of $2.0 \mu \mathrm{g} / \mathrm{g}$.

\section{Stream Sampling}

Water and bottom-material samples were collected at stream-sampling sites during periods of high flow and base flow in May and September 1991 and 1992. Bottom material was not collected at sites S2 (Alva B. Adams Tunnel at East Portal near Estes Park) and S3 (Willow Creek Pump Canal near Granby; table 1) because of an absence of bottom material due to the concrete channel. Water samples were not collected in September 1991 and 1992 at site S3 (Willow Creek Pump Canal near Granby) due to zero flow conditions.

Water-quality samples were collected using standard sampling techniques (Ward and Harr, 1990). A depth-integrating sampler was used to collect waterquality samples using the equal-width-increment (EWI) method at the sampling-site channel cross section (Guy and Norman, 1970). The water samples were transferred from the depth-integrating sampler into a churn splitter for a composite sample.

Sample preparation and preservation were completed onsite. Samples analyzed for total concentrations were decanted into sample bottles from the churn splitter while slowly agitating the water and suspended-sediment mixture. The samples analyzed for total recoverable silver were decanted into $250-\mathrm{mL}$ polyethylene bottles and preserved at $\mathrm{pH} 2$ or less using nitric acid. Samples for analysis of dissolved silver concentrations were pumped from the churn splitter through a $0.45 \mu \mathrm{m}$ cellulose-membrane filter into $250-\mathrm{mL}$ Teflon bottles and preserved at $\mathrm{pH} 2$ or less using ultrapure nitric acid. The filter assembly and a newly installed filter were flushed with $1 \mathrm{~L}$ deionized 


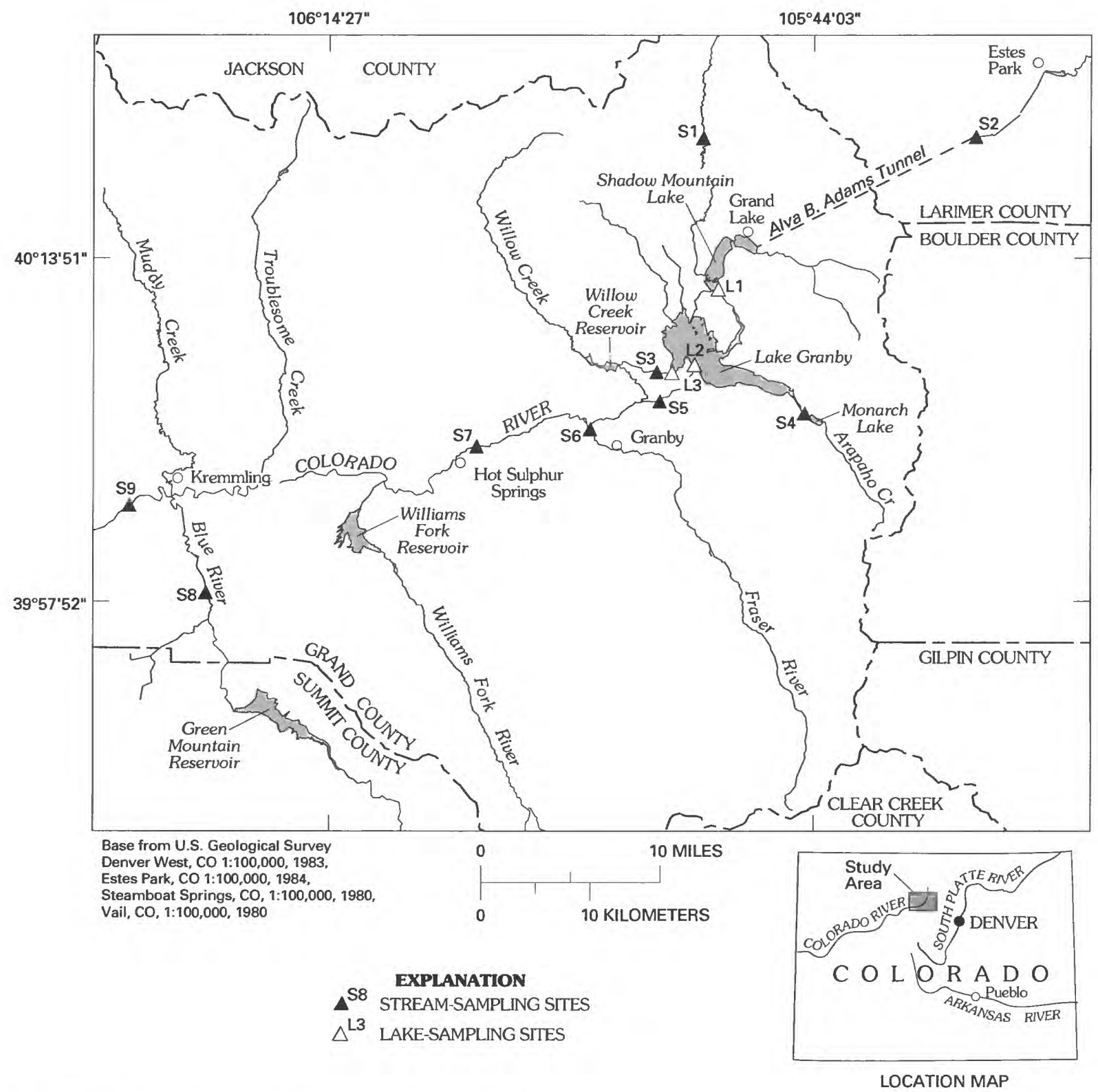

Figure 1. Location of study area and sampling sites. 


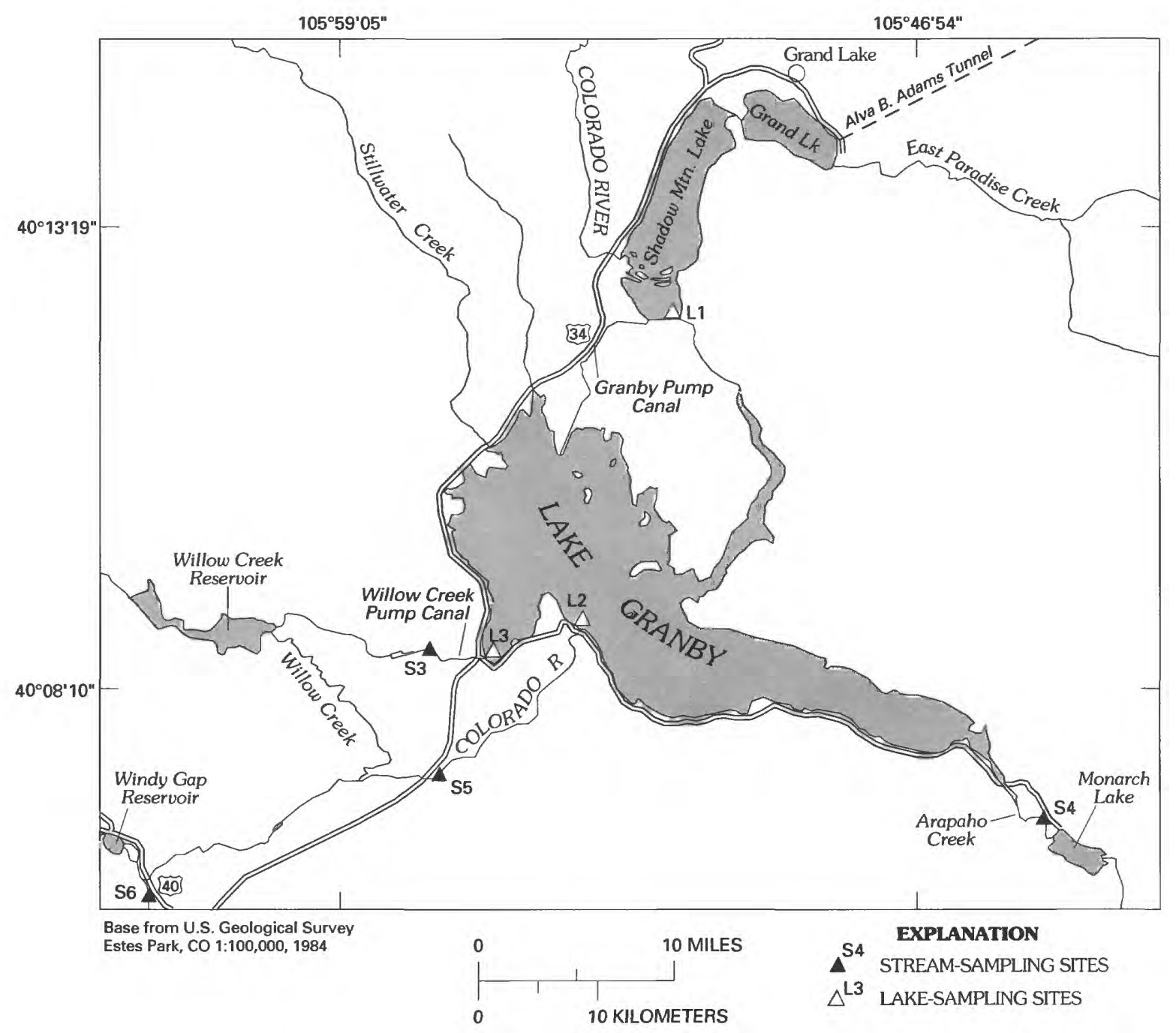

Figure 2. Shadow Mountain Lake and Lake Granby sampling sites. 


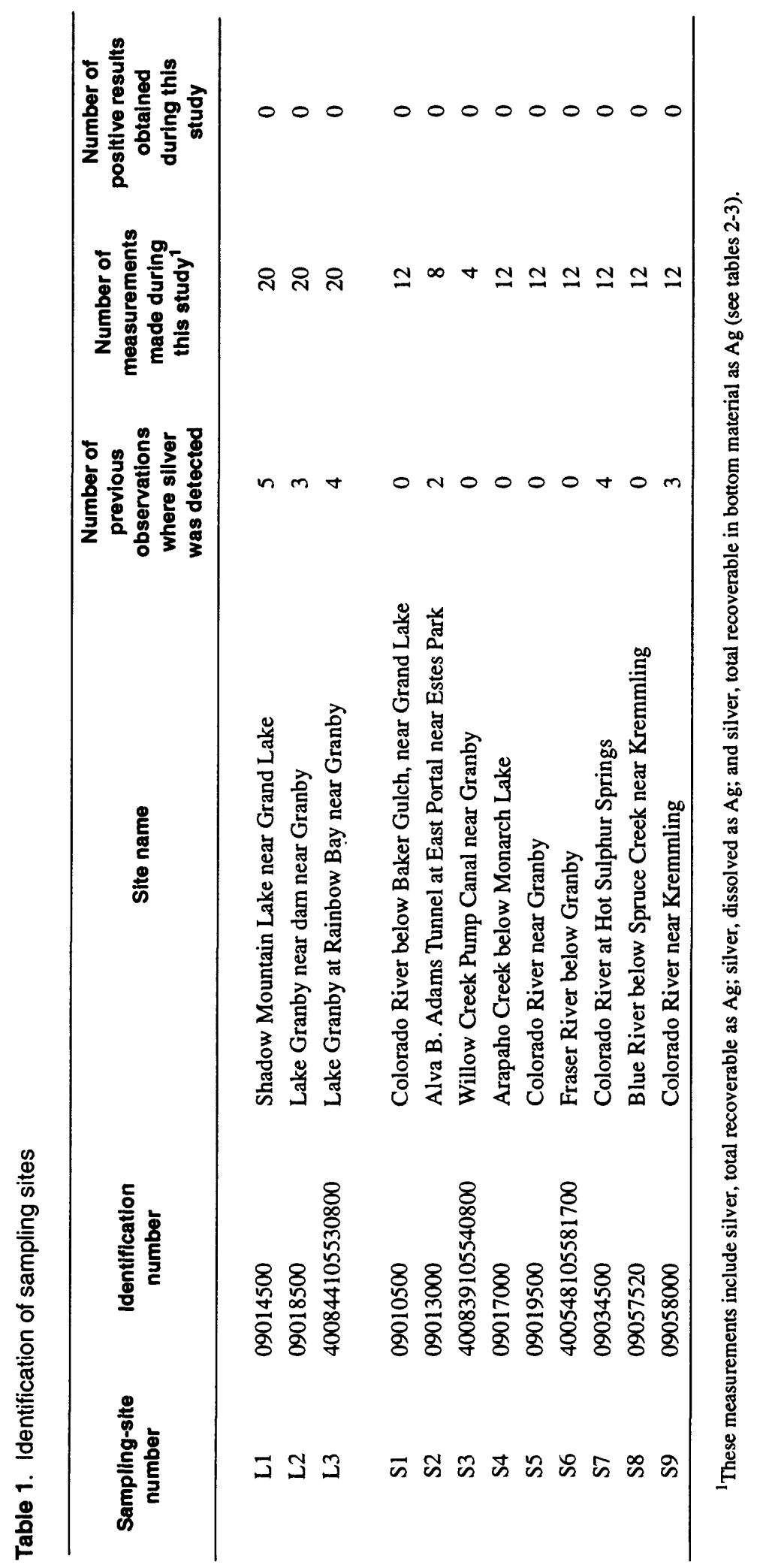


water prior to filtering at each site. The depth-integrating sampler and churn splitter were triple rinsed with deionized water and native water before water samples were collected at each sampling site.

Bottom-material samples were collected at six of the nine stream-sampling sites for concentrations of total recoverable silver. Once the sedimentation areas were located at each of the sampling sites, a sample of the top $1 \mathrm{in}$. of fine bottom material was extracted with a hand scoop. The scoop was slowly raised through the water column taking care to avoid washing away the fine materials. Nearly all the depositional areas of the freshly deposited fine bottom material were located in parts of the stream with low or zero flow. The sample was placed in a $500-\mathrm{mL}$ wide-mouth polypropylene bottle and stored in a cooler for transport to the USGS Lakewood office for further processing. A 1-L native water sample was collected at each bottom-material sampling site to be used for laboratory wet sieving of the sediment processing prior to analysis.

The bottom-material samples were sieved through a $60-\mu \mathrm{m}$ nylon mesh screen using native water from the corresponding sampling site. The sieved samples were then dewatered by baking the samples in an oven at about $50^{\circ} \mathrm{C}$ for about 48 hours prior to being submitted to the USGS Branch of Geochemistry Laboratory for concentration analysis.

Onsite measurements made at the streamsampling sites were specific conductance, $\mathrm{pH}$, and water temperature. Streamflow was computed from the individual discharge-rating tables for each gaging station using the observed gage height at the time of the site visit.

\section{Lake Sampling}

Water and bottom-material samples were collected from two sampling sites in Lake Granby (L2, L3) and one site in Shadow Mountain Lake (L1) (fig. 2). The sampling was done in May and September 1991 and 1992.

Water-quality samples were collected just below the water surface and just above the lake bottom by using a vertically suspended Van Dorn sampler. The Van Dorn sampler consisted of a polyvinyl chloride (PVC) cylinder with rigid polyurethane end seals, silicone gaskets, and a latex closing tube. It was about $2 \mathrm{ft}$ long and had a capacity of about $4 \mathrm{~L}$. Samples analyzed for total concentrations were decanted into the proper polyethylene sample bottles directly from the Van Dorn sampler. Samples analyzed for dissolved concentrations were decanted into clean $4-\mathrm{L}$ polyethyl- ene jugs for transport to the laboratory vehicle for processing and preservation.

Sample preparation and preservation were completed in a field laboratory vehicle in the same manner described in the "Stream Sampling" section of this report, except that samples analyzed for dissolved concentrations were pumped for filtration from the 4-L jugs instead of the churn splitter.

Lake-bottom samples were collected after the water-quality samples were obtained. Bottom material was analyzed for concentrations of total recoverable silver. A 9-in. by 9-in. Eckman dredge was used to collect bottom material from the lakes. The dredge was suspended by a hand line and slowly lowered to the bottom. Once contact was made with the lake bottom, a messenger was sent down the hand line to trip the dredge-closing mechanism. The dredge was slowly raised to the surface, brought onboard the boat, and subsamples of the top 1-in. of sediment were scooped out of the dredge and placed into $500-\mathrm{mL}$ wide-mouth polypropylene sample containers. The samples were placed in coolers to be transported back to the USGS Lakewood office for further processing. A 1-L native water sample was collected at each bottom-material sampling site to be used for the wet sieving of the sediment upon return to the Lakewood office. The lake bottom-material samples were sieved using the same techniques described in the "Stream Sampling" section of this report.

Onsite measurements of specific conductance, $\mathrm{pH}$, and water temperature were made at all three lakesampling sites using a multiparameter in-situ measuring instrument. Light transparency was measured with a black and white 8-in.-diameter Secchi disk. Limnological characteristics regarding lake profiles are reported in Ugland and others $(1992,1993)$.

\section{QUALITY-ASSURANCE PROCEDURES}

Specific quality-assurance (QA) procedures for sampling were followed. Field-blank samples were prepared at the beginning and end of each sampling trip as a QA check against contamination from sampling and filtering equipment. Duplicate samples for analysis of total and dissolved silver concentrations were collected at surface and bottom depths at one of the lake sites and from at least one stream site during each sampling trip. These samples were submitted to the laboratory separately as a QA check of analytical procedures. Duplicate samples of bottom material also were collected at one of the lake sites and from at least one stream site during each sampling trip. The laboratory results for QA were used for verification purposes only and are not included in this report. QA for the onsite measurements consisted of proper equipment 
inspection and calibration. None of the QA samples collected and analyzed indicated any measurable concentrations of silver.

\section{RESULTS}

Results of silver concentrations and selected hydrologic data for stream-sampling sites and for Shadow Mountain Lake and Lake Granby are listed in tables 2 and 3 in the "Hydrologic Data" section at the back of this report.

The silver concentrations of water samples collected were less than the detection limit of $0.2 \mu \mathrm{g} / \mathrm{L}$ for the samples analyzed for dissolved silver and $1.0 \mu \mathrm{g} / \mathrm{L}$ for the samples analyzed for total recoverable silver from all sampling sites during the study. Silver concentrations in the bottom material were less than the detection limit of $2.0 \mu \mathrm{g} / \mathrm{g}$ at all sampling sites.

\section{REFERENCES}

Baedecker, P. A., ed., 1987, Methods for geochemical analysis: U.S.Geological Survey Bulletin 1770, 132 p.
Edwards, T.K., and Glysson, G.D., 1988, Field methods for measurement of fluvial sediment: U.S. Geological Survey Open-File Report 86-531, 118 p.

Fishman, M.J., and Friedman, L.C., eds., 1989, Methods for determination of inorganic substances in water and fluvial sediments ( $3 \mathrm{~d}$ ed.): U.S. Geological Survey Techniques of Water-Resources Investigations, bk. 5, chap. A1, $545 \mathrm{p}$.

Guy, H.P., and Norman, V.W., 1970, Field methods for measurement of fluvial sediment: U.S. Geological Survey Techniques of Water-Resources Investigations, bk. 3, chap. C2, 59 p.

U.S. Environmental Protection Agency, 1986, Quality criteria for water 1986: EPA 440/5-86-001, various paging.

Ugland, R.C., Cochran, B.J., Hiner, M.M., Wilson, E.A., Bennett, J.D., and Jenkins, R.A., 1992, Water Resources Data, Colorado, Water Year 1991: U.S. Geological Survey Water-Data Report CO-91-2, 416 p. 1993, Water Resources Data, Colorado, Water Year 1992: U.S. Geological Survey Water-Data Report CO-92-2, $406 \mathrm{p}$.

Ward, J.R., and Harr, C.A., eds., 1990, Methods for collection and processing of surface-water and bed-material samples for physical and chemical analyses: U.S. Geological Survey Open-File Report 90-140, 71 p. 
HYDROLOGIC DATA 


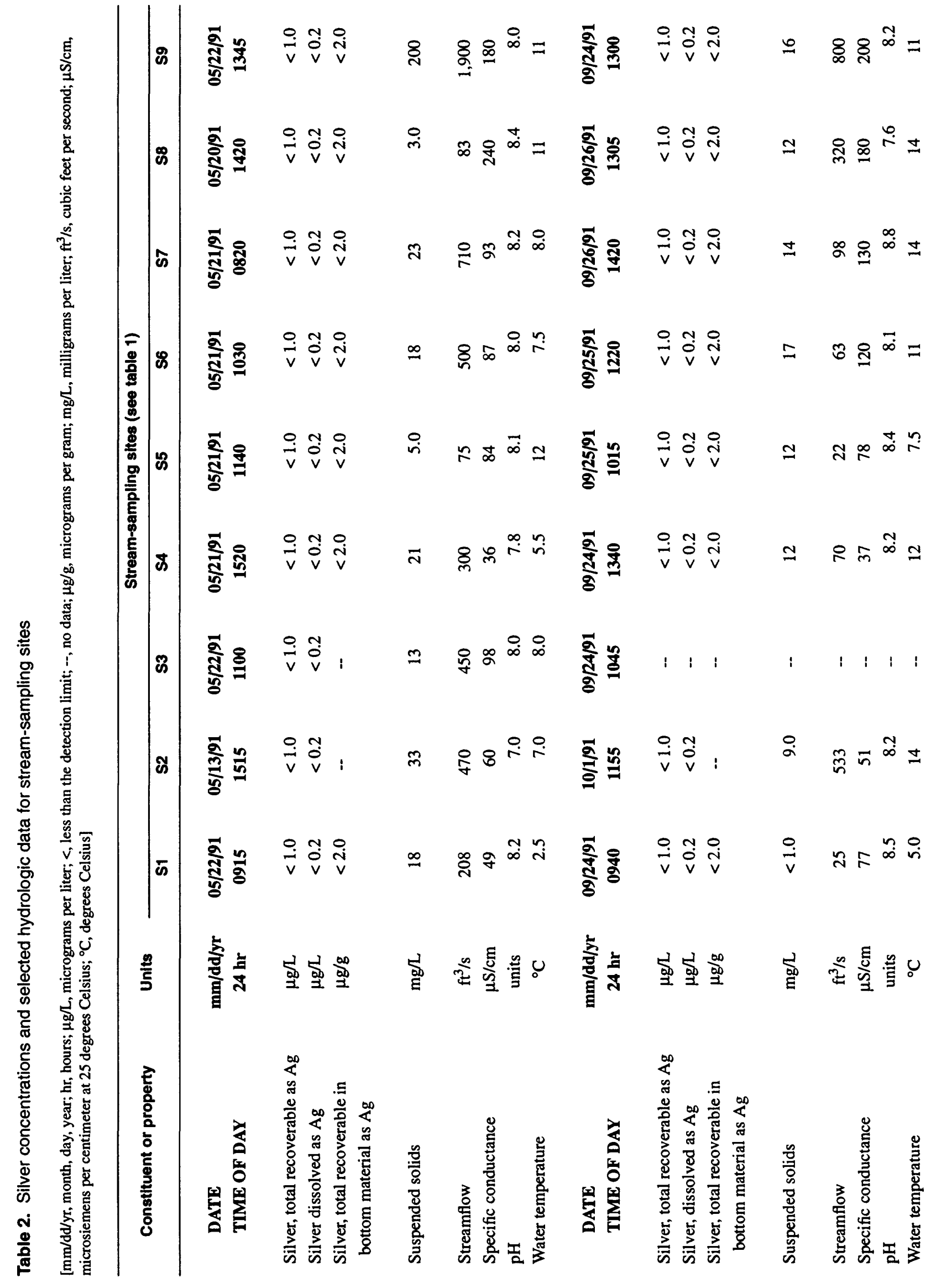




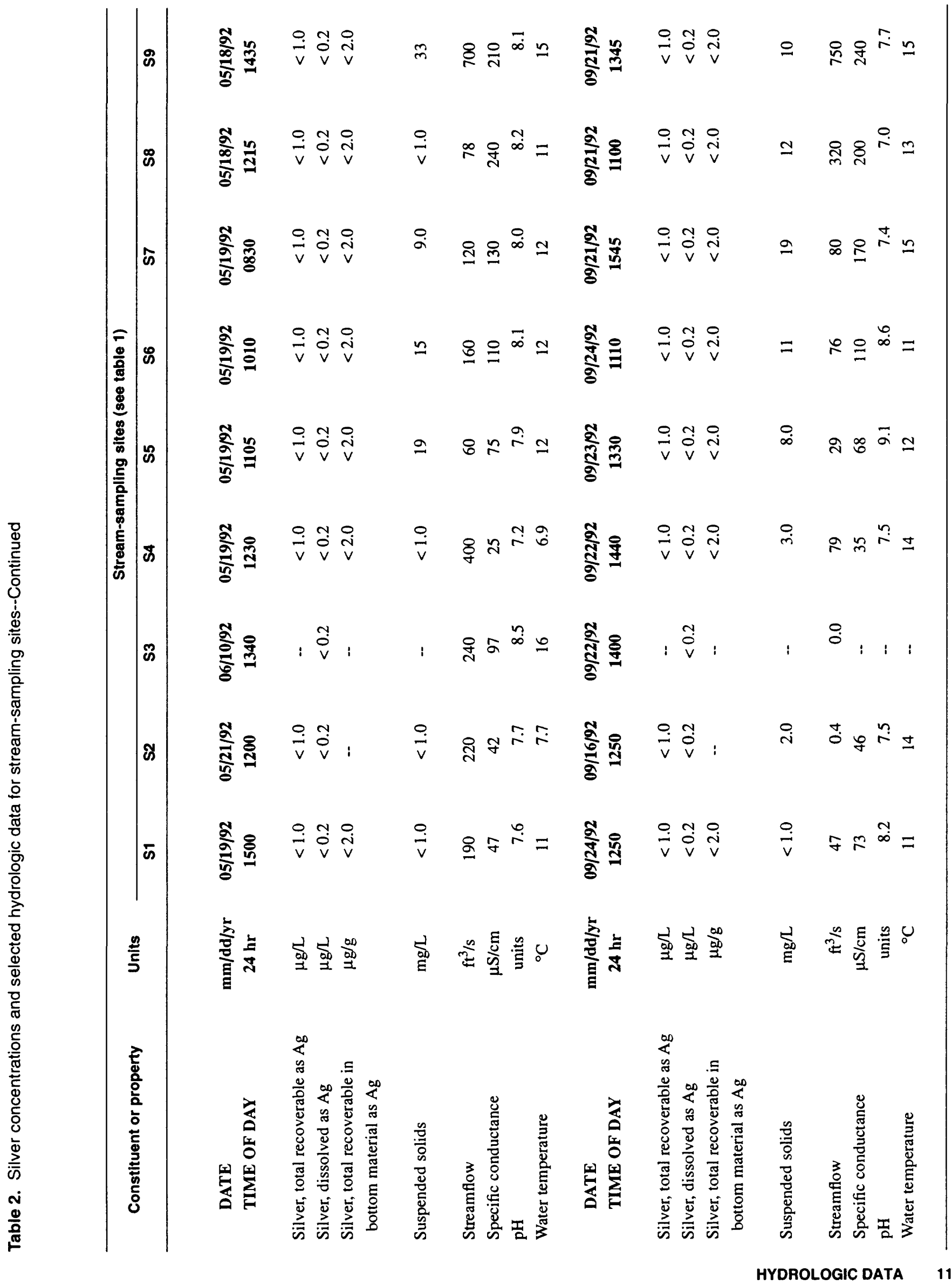




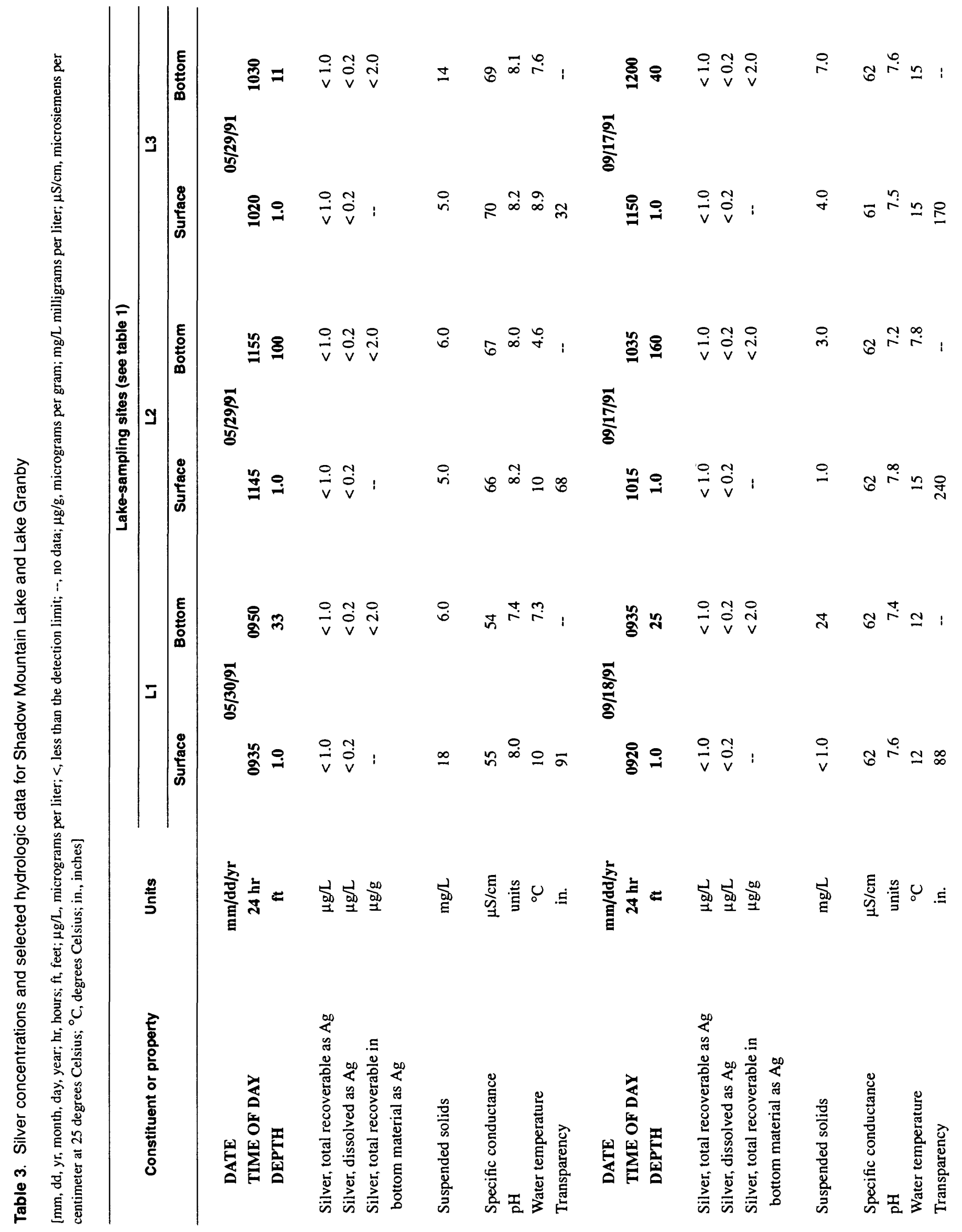




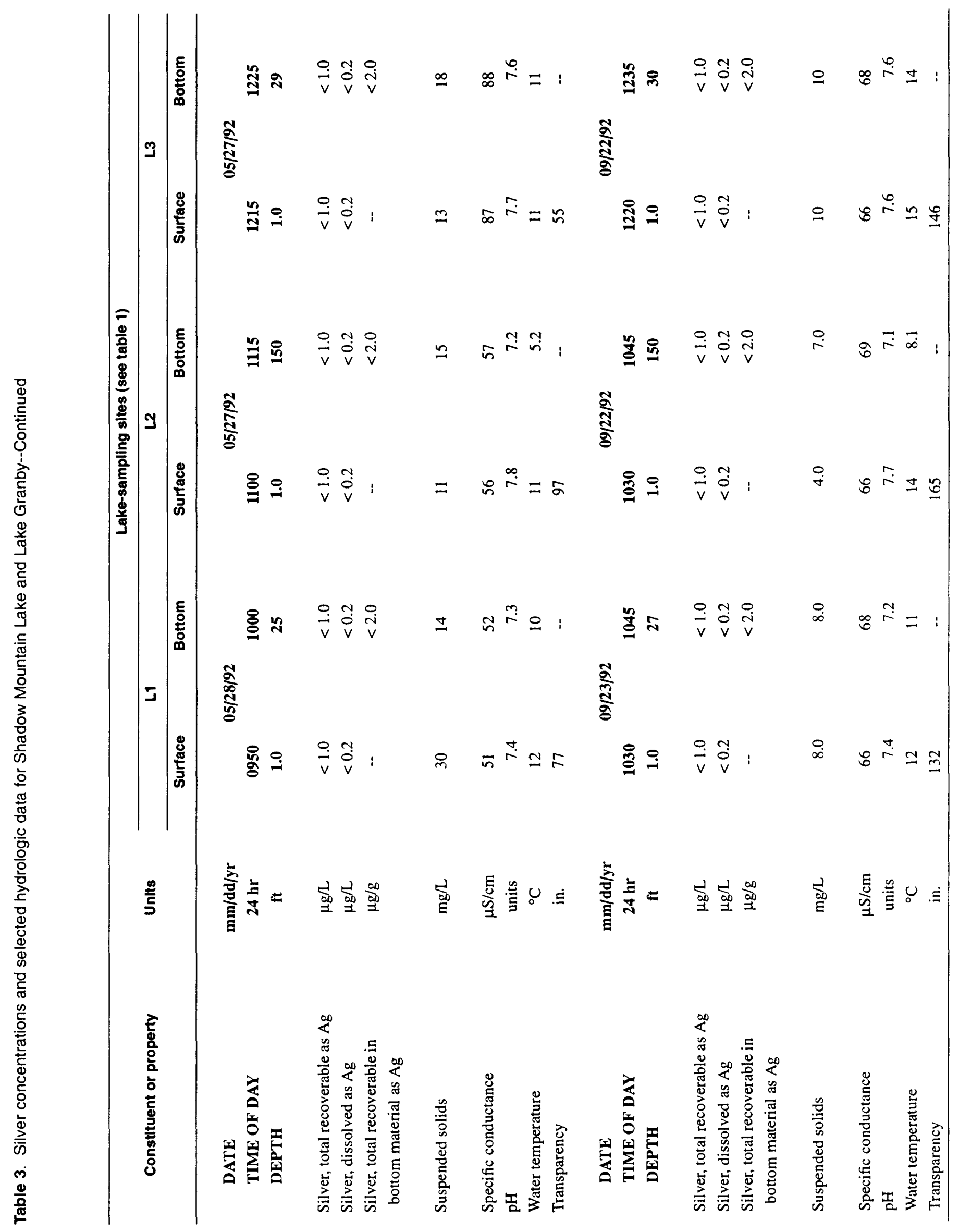

HYDROLOGIC DATA 13

\ U.S. GOVERMMENT PRINTING OFFICE: 1993-573-191 / 80007 REGION NO. 8 